\title{
Knowledge of HPV and HPV vaccine among senior secondary school students in Nigeria: Implications on cancer prevention strategies, the CHANCE Study
}

\author{
Omotayo F. Fagbule ${ }^{1,2}$, Kehinde K. Kanmodi',2, Emmanuel O. Aliemeke ${ }^{1}$, Kayode E. Ogunniyi ${ }^{1}$, Mike Ogbeide ${ }^{1,2}$, Samuel 0. \\ Victor $^{1}$, Taiwo O. Isola ${ }^{1}$, Habeeb 0. Adewuyi ${ }^{1}$, Semeeh A. Omoleke ${ }^{3}$, Precious A. Kanmodi ${ }^{1,2}$
}

\section{AFFILIATION}

1 Cephas Health Research Initiative Inc, Ibadan, Nigeria

2 Mental and Oral Health Development Organization, Birnin Kebbi, Nigeria

3 World Health Organization, Kebbi State Field Office, Birnin Kebbi, Nigeria

CORRESPONDENCE TO

Kehinde K. Kanmodi. Cephas Health Research Initiative Inc, Ibadan, Nigeria. E-mail: kanmodikehinde@yahoo.com

\section{KEYWORDS}

human papillomavirus, vaccine, secondary school students, Nigeria, awareness, knowledge

Received: 8 April 2020, Revised: 16 July 2020, Accepted: 3 September 2020

\begin{abstract}
INTRODUCTION Human papillomavirus (HPV) is one of the major causes of head and neck cancer (HNC). The incidence rate of newly diagnosed HPV-induced HNC cancer is on the rise, year-by-year; this is a problem of public health concern. This study aims to determine the prevalence and predictors of knowledge of senior secondary (high) school students in Nigeria on HPV and HPV vaccines.

METHODS This study was a cross-sectional survey of 2530 high school students from six states in Nigeria using a selfadministered structured questionnaire. Data collected were analyzed using the SPSS version 25 software.

RESULTS The mean $( \pm$ SD) age of the respondents was $16.4( \pm 2.0)$ years, $56.0 \%$ were male and $34.9 \%$ were from the Yoruba ethnic group. Only $23.0 \%$ and $18.3 \%$ of the respondents were aware of HPV and HPV vaccine, respectively. The majority (78.2\%) of those who were
\end{abstract}

aware of HPV had below-average knowledge score about HPV. Those respondents: in the highest class in high school (AOR=1.36; $\mathrm{CI}=1.00-1.84 ; \mathrm{p}=0.048)$; attending girls-only schools (AOR=2.86; CI: 1.93-4.24; $\mathrm{p}<0.001$ ); and schooling in Bauchi state (AOR=2.56; CI: 1.47-4.51; $\mathrm{p}=0.001$ ) were most likely to be aware of HPV compared to those in the other categories. However, those: attending girls-only ( $\mathrm{AOR}=2.80$; $\mathrm{CI}$ : 1.84-4.27; $\mathrm{p}<0.001$ ); schooling in Bauchi state (AOR=2.87; $\mathrm{CI}$ : $1.55-5.33 ; \mathrm{p}=0.001$ ); and belonging to the Hausa tribe $(\mathrm{AOR}=2.41$; $\mathrm{CI}: 1.51-3.85 ; \mathrm{p}<0.001)$ were most likely to be aware to HPV vaccine than those in other categories.

CONCLUSIONS The level of knowledge of HPV and HPV vaccine among high school students in Nigeria is very poor. There is a need for health education programs on HPV and HPV vaccines in Nigerian secondary schools.

\section{INTRODUCTION}

Human papillomavirus (HPV) is a double-stranded DNA virus, which belongs to the family of Papillomaviridae ${ }^{1,2}$. There are over 100 types of HPV and they include HPV types $6,11,16,18,31,33,35,39$, and others ${ }^{3,4}$. However, about $30 \mathrm{HPV}$ types are known to cause HPV-induced anogenital and oral infections ${ }^{5}$. These infectious HPVs are further categorized as 'low risk' and 'high risk' HPVs based on the clinical manifestations associated with the lesions they cause $\mathrm{e}^{5}$. The low risk HPVs are responsible for causing benign epithelial hyperplasias (i.e. warts) while the high risk HPVs are responsible for causing malignant lesions (i.e. cancers) $)^{5,6-9}$.

The high risk HPVs are also called oncogenic HPVs. Oncogenic HPVs (such as HPV 16 and 18) are responsible for almost $100 \%, 90 \%, 70 \%, 50 \%, 40 \%$, and $13-72 \%$ of cervical, anal, vaginal, penile, vulvar, and oropharyngeal cancers, respectively ${ }^{6-9,10-12}$. Every year, about 0.51 million women are newly diagnosed with invasive cervical cancer while 0.288 million women die as a result of the disease. Furthermore, approximately $80 \%$ of newly reported cervical cancer cases are from the developing world ${ }^{13}$. Similarly, about 30000 new 
cases of oropharyngeal cancers are reported yearly ${ }^{14}$.

There are various routes of transmission of HPV. The virus can be transmitted through sexual contact (e.g. anal sex, penetrative vaginal sex, and oral sex), skin-to-skin contact, and through child delivery (from mother to child) ${ }^{15-19}$.

The lifetime risk of HPV infection is as high as $80 \%{ }^{20}$. Fortunately, HPV infection is a vaccine-preventable disease ${ }^{3}$. As a way of reducing the heavy burden of HPV-associated diseases among their populace, countries like Australia, USA, Norway, Austria, and Germany had included HPV vaccination programs into their routine immunization programs, years back $^{21}$. Through massive vaccination campaigns against HPV, many people in these countries have been protected against HPV-associated diseases ${ }^{21}$. Unfortunately, in Nigeria, HPV vaccination is yet to be introduced into its national routine immunization programs despite the very high prevalence rate of HPV-associated diseases among its populace ${ }^{22,23}$.

Generally, young people are known to be a highly vulnerable population group when it comes to the risk of contracting HPV infections ${ }^{24-26}$. This assertion was made based on the rising rate of risky sexual behaviors (such as unprotected oral, vaginal and anal sexual intercourse) among the population group, coupled with the lack of a history of vaccination against HPV infection among them ${ }^{22,23,26}$.

In Nigeria, only very few and limited studies have assessed the knowledge of in-school young persons on HPV and HPV vaccines. Therefore, it will be of huge public health benefit if the prevalence and predictors of knowledge of young people in Nigeria on HPV and HPV vaccine are known, as such information will go a long way in helping the Nigerian government and other relevant stakeholders on how to develop, promote, and implement public health policies/ programs that will mitigate the community spread of the virus among them and also encourage their uptake of HPV vaccine.

This study was conducted with the aim of determining the prevalence and predictors of knowledge of senior secondary (high) school students (a population group that is predominantly made up of adolescents) in Nigeria on HPV and HPV vaccine. Conducting this kind of study amongst this population group is of high relevance because: 1) roughly 1 in 10 adolescents in Nigeria are sexually active ${ }^{27-32} ; 2$ ) the knowledge of HPV and HPV vaccine among Nigerian adolescents reflects their collective level of preparedness towards the prevention of HPV transmission; and 3) the outcomes of this study will help to inform all relevant stakeholders in the Nigerian public health sector on how to effectively formulate, promote, and implement school health education policies/programs targeted at mitigating the spread of HPV infection among adolescents in Nigeria.

\section{METHODS}

\section{Study design}

This study was a descriptive cross-sectional populationbased study that was conducted in order to assess the level of knowledge of senior secondary school students in Nigeria on HPV and HPV vaccine. Also, this study forms part of the multi-year 'Campaign for Head And Neck Cancer Education (CHANCE)' Program conducted under the aegis of the Cephas Health Research Initiative Inc, Nigeria ${ }^{33-42}$.

Five geopolitical zones (south-west, south-south, northeast, north-west, and north-central), out of 6 geopolitical zones in Nigeria were randomly selected for the study. One state was randomly selected per zone, with the exception of the south-west zone where two states were selected. Using convenient sampling technique, a minimum of two schools were selected per state for the study. However, simple random sampling technique was used in the selection of the study participants. For a student to be considered eligible to participate in this study, he/she must belong to any of the senior classes (Senior Secondary Classes, SS1, SS2 and SS3) in a secondary school situated within Nigeria; and he/she must also be willing to participate.

\section{Study instrument}

The instrument used for the data collection was a selfadministered structured questionnaire that was developed through literature search ${ }^{4-49}$ and through a thorough review and editing process by a certified health education specialist (CHES). The questionnaire was anonymous and obtained information about sociodemographic characteristics (sex, age, tribe, religion, class, school etc.), knowledge of HPV, and knowledge of HPV vaccines from the participants.

\section{Measures}

\section{Awareness of HPV and HPV vaccine}

These were assessed using the questions: 'Have you ever heard of the Human Papillomavirus (HPV)?' and 'Have you ever heard of HPV vaccine?', respectively. The response options were 'Yes', 'No', or 'I don't know'. Those that responded in the affirmative were considered as being aware of HPV and HPV vaccine, respectively.

\section{Knowledge of HPV and HPV vaccine}

Nineteen questions were used to assess knowledge of HPV among those participants who identified themselves to be aware of HPV, while five questions were used to assess the knowledge of HPV vaccine among those participants who identified themselves to be aware of HPV vaccine. The response options to virtually all these questions were 'Yes', 'No', or 'I don't know'. Every correct response was given a score of ' 1 ' and other responses were given a score of ' 0 '. The total knowledge score on HPV and HPV vaccine was calculated for each participant, with the highest achievable score being '19' and '5' for HPV and HPV vaccine, respectively.

\section{Data collection and entry}

Between November 2016 and January 2018, a total of 3000 students who fulfilled the study's eligibility criteria were approached for the study. They were informed about the purpose of the study. They were also informed that 
their participation is strictly voluntary and completely confidential. Only those students (2754) that agreed to participate and who also gave written informed consent were recruited and issued a self-administered questionnaire to fill in. A total of 2701 students returned their questionnaires to the investigators, giving a response rate of $98.1 \%$. During the data cleaning process, 171 questionnaires were excluded from the study because a significant proportion of their content was inappropriately/not filled in. Finally, only 2530 filled questionnaires were considered for data analysis.

This study was conducted under strict compliance with the 1964 Helsinki Declaration on health research involving human subjects. Ethical clearance to conduct this study was obtained from the University of Ibadan, University College Hospital Institutional Review Board, Ibadan, Nigeria. Approval was also obtained from the participating schools. All participants were informed about the purpose of the study; they were also informed that their participation was completely voluntary and strictly confidential. Informed consent was obtained from the participants (i.e. SS1 to SS3 students), class teachers, and parents. All participation was voluntary. No participant was harmed as a result of the study.

\section{Data analysis}

Only the data obtained from the appropriately filled in questionnaires were analyzed using SPSS version 25 software. Frequency distribution of all variables was determined. The frequency distributions of all variables were obtained and the mean scores (and standard deviations) of the respondents' age, knowledge of HPV, and HPV vaccine, were determined. Pearson's chi-squared test was used to compare the sociodemographic characteristics of those respondents who were aware of HPV and HPV vaccine with their responses to the questions/statements assessing their knowledge on HPV and HPV vaccine, respectively. Also, those respondents who had average and/or above average scores on HPV and HPV vaccine were determined, classified and compared with the independent variables (sociodemographics) using Pearson's chi-squared test. Multivariable logistic regression modeling was also done to determine the factors predicting the respondents' knowledge of HPV and HPV vaccine. A $p<0.05$ was used to determine the level of statistical significance in the comparisons.

\section{RESULTS}

\section{Sociodemographic data}

This study was conducted across six states, spreading across five geopolitical zones in Nigeria. One-fifth (20.9\%) of the 2530 respondents were from Benue state (in the north-central zone of Nigeria). Their mean age $( \pm$ SD) was $16.4( \pm 2.0)$ years, $56.0 \%$ were male, $34.9 \%$ belonged to the Yoruba tribe, $60.8 \%$ were Christians, $51.7 \%$ had monogamous family background, $73.5 \%$ were attending public schools, $78.1 \%$ were attending day-schools, and 31.3\% were in SS1 (Table 1).
Table 1. Sociodemographic characteristics of respondents $(\mathrm{N}=2530)$

\begin{tabular}{l|c|c|} 
Variables & $\begin{array}{c}\text { Frequency/ } \\
\text { value }\end{array}$ & $\begin{array}{c}\text { Percentage } \\
(\%)\end{array}$ \\
\hline State & & \\
Osun & 464 & 18.3 \\
Oyo & 370 & 14.6 \\
Bauchi & 357 & 14.1 \\
Sokoto & 424 & 16.8 \\
Edo & 385 & 15.2 \\
Benue & 530 & 20.9 \\
School type & & \\
Public & 1860 & 73.5 \\
Private & 670 & 26.5 \\
Mode of studentship & & \\
Boarding & 554 & 21.9 \\
Day & 1976 & 78.1 \\
Class & & \\
SS3 & 817 & 32.3 \\
SS2 & 831 & 32.8 \\
SS1 & 791 & 31.3 \\
No response & 91 & 3.6 \\
Age (years) & & \\
Youth ( $\geq 20)$ & 138 & 5.5 \\
Late adolescence (15-19) & 1999 & 79.0 \\
Early adolescence (10-14) & 372 & 14.7 \\
No response & 21 & 0.8 \\
Mean age ( $\pm S D)$ & 16.4 ( \pm 2.0$)$ & \\
Gender & & \\
Male & 1418 & 56.0 \\
Female & 1088 & 43.0 \\
No response & 24 & 1.0 \\
Religion & & \\
Christianity & 1537 & 60.8 \\
Islam & 959 & 37.9 \\
Traditional/pagan/other & 20 & 0.8 \\
No response & 14 & 0.6 \\
\hline Family backgend & \\
\hline & & \\
\hline
\end{tabular}

$\begin{array}{lrr}\text { Family background } & & \\ \text { Polygamous/other } & 743 & 29.4 \\ \text { Single parent } & 326 & 12.9 \\ \text { Monogamous } & 1307 & 51.7 \\ \text { No response } & 154 & 6.1 \\ \text { Tribe } & & \\ \text { Yoruba } & 884 & 34.9 \\ \text { Hausa } & 599 & 23.7 \\ \text { Igbo } & 250 & 9.9 \\ \text { Other } & 797 & 31.5 \\ \text { School composition } & & \\ \text { Mixed } & 1749 & 69.1 \\ \text { Boys only } & 551 & 21.8 \\ \text { Girls only } & 230 & 9.1\end{array}$

SD: standard deviation. 
Prevalence of awareness and knowledge of HPV and HPV vaccine

Only $23.0 \%$ and $18.3 \%$ of the respondents were aware of HPV and HPV vaccines, respectively (Supplementary file,

Table 2. Sociodemographic factors associated with awareness of HPV and HPV vaccine, among those respondents that were aware of each one

\begin{tabular}{|c|c|c|c|c|}
\hline \multirow[t]{2}{*}{ Variable } & \multicolumn{2}{|c|}{ HPV } & \multicolumn{2}{|c|}{ HPV vaccine } \\
\hline & Yes* (\%) & p\# & Yes* (\%) & p\# \\
\hline Age (years) & & 0.001 & & 0.016 \\
\hline $\begin{array}{l}\text { Early adolescence } \\
(10-14)\end{array}$ & $64(17.2)$ & & $51(13.7)$ & \\
\hline $\begin{array}{l}\text { Late adolescence } \\
(14-19)\end{array}$ & 467 (23.4) & & 372 (18.6) & \\
\hline Youth ( $\geq 20$ ) & 44 (31.9) & & 33 (23.9) & \\
\hline State & & $<0.001$ & & $<0.001$ \\
\hline Osun & $93(20.0)$ & & $66(14.2)$ & \\
\hline Оуо & 83 (22.4) & & $60(16.2)$ & \\
\hline Bauchi & 140 (39.2) & & 119 (33.3) & \\
\hline Sokoto & 77 (18.2) & & 83 (19.6) & \\
\hline Edo & $71(18.4)$ & & $50(13.0)$ & \\
\hline Makurdi & $119(22.5)$ & & 84 (15.8) & \\
\hline Religion & & 0.001 & & $<0.001$ \\
\hline Christianity & $315(20.5)$ & & 225 (14.6) & \\
\hline Islam & $254(26.5)$ & & $224(23.4)$ & \\
\hline Tribe & & 0.007 & & $<0.001$ \\
\hline Yoruba & $209(23.6)$ & & $144(16.3)$ & \\
\hline Hausa & $164(27.4)$ & & $170(28.4)$ & \\
\hline Igbo & $53(21.2)$ & & 38 (15.2) & \\
\hline Others & 157 (19.7) & & $110(13.8)$ & \\
\hline Type of school & & $<0.001$ & & $<0.001$ \\
\hline Public & $379(20.4)$ & & $300(16.1)$ & \\
\hline Private & $204(30.4)$ & & $162(24.2)$ & \\
\hline $\begin{array}{l}\text { School } \\
\text { composition }\end{array}$ & & $<0.001$ & & $<0.001$ \\
\hline Mixed & $381(21.8)$ & & $290(16.6)$ & \\
\hline Boys only & $119(21.6)$ & & $110(20.0)$ & \\
\hline Girls only & 83 (36.1) & & $62(27.0)$ & \\
\hline Class & & $<0.001$ & & $<0.001$ \\
\hline SS1 & $140(17.7)$ & & $116(14.7)$ & \\
\hline SS2 & $219(26.4)$ & & $179(21.5)$ & \\
\hline SS3 & 195 (23.9) & & 146 (17.9) & \\
\hline
\end{tabular}

HPV: human papillomavirus. *All percentages were calculated based on the total number of eligible respondents per category (i.e. total responses per category/total number of eligible respondents). \#Only the data on sociodemographic variables that yielded statistically significant comparisons with HPV awareness, and HPV vaccine awareness, are presented.
Tables S1 and S2). Among those that were aware of HPV $(n=583)$, the sources of their information were: TV/radio/ magazines (28.5\%); internet (17.5\%); health-workers (11.3\%); friends (18.5\%); and parents (10.6\%) (Table S1). The majority (78.2\%) of those who were aware of HPV had below-average knowledge score in their assessment on HPV (Table S1).

As for those who were aware of HPV vaccine $(n=462)$, the sources of their information were: the internet (22.5\%); school (18.4\%); TV/radios (16.7\%); health-workers (14.3\%); posters in pharmacies (14.3\%); student health centers (8.7\%); information leaflets (6.1\%); and other (4.3\%). Their mean $( \pm S D)$ knowledge score regarding their knowledge assessment on HPV vaccine was $1.0( \pm 1.2)$. The majority $(74.0 \%)$ had below average knowledge about the HPV vaccine (Table S2).

\section{Factors associated with awareness of HPV and HPV vaccine}

Table 2 shows that a higher proportion of those respondents who were: aged $\geq 20$ years (31.9\%), from the Hausa tribe (27.4\%); and attending private secondary schools (30.4\%) were aware of HPV compared to: the adolescent respondents; those who were non-Hausas; and those attending public secondary schools, respectively $(\mathrm{p}<0.05)$.

\section{Factors associated with knowledge of HPV and HPV vaccine}

Table 3 shows that the respondents' state of residence, tribe, and gender were significantly associated with their knowledge of HPV and HPV vaccine. In addition, the family background, religion, and school composition of the respondents were significantly associated with their knowledge of HPV vaccine.

\section{Table 3. Sociodemographic factors associated with} the knowledge of HPV and HPV vaccine, among those respondents that were aware of each one

\begin{tabular}{l|c|c|c|c|}
\hline Variable & $\begin{array}{c}\text { Average } \\
\text { and above } \\
\text { average } \\
\text { score on } \\
\text { HPV* (\%) }\end{array}$ & $\begin{array}{c}\text { Above } \\
\text { average } \\
\text { score } \\
\text { on HPV } \\
\text { vaccine* } \\
(\%)\end{array}$ & p\# \\
State & & 0.002 & & $<0.001$ \\
Osun & $30(32.3)$ & $13(19.7)$ & \\
Oyo & $28(33.7)$ & $12(20.0)$ & \\
Bauchi & $26(18.6)$ & $43(36.1)$ & \\
Sokoto & $12(15.6)$ & $32(38.6)$ & \\
Edo & $12(16.9)$ & $10(20.0)$ & \\
Makurdi & $19(16.0)$ & $10(11.9)$ &
\end{tabular}


Table 3. Continued

\begin{tabular}{|c|c|c|c|c|}
\hline Variable & $\begin{array}{c}\text { Average } \\
\text { and above } \\
\text { average } \\
\text { score on } \\
\text { HPV }^{*}(\%)\end{array}$ & p\# & $\begin{array}{c}\text { Above } \\
\text { average } \\
\text { score } \\
\text { on HPV } \\
\text { vaccine* } \\
(\%)\end{array}$ & p\# \\
\hline Tribe & & 0.020 & & 0.008 \\
\hline Yoruba & 60 (28.7) & & $36(25)$ & \\
\hline Hausa & 32 (19.5) & & $58(34.1)$ & \\
\hline Igbo & 10 (18.9) & & 8 (21.1) & \\
\hline Others & 25 (15.9) & & $18(16.4)$ & \\
\hline Gender & & 0.025 & & $<0.001$ \\
\hline Male & $83(25.3)$ & & $89(34.2)$ & \\
\hline Female & 43 (17.5) & & 29 (14.9) & \\
\hline Religion & & 0.589 & & 0.001 \\
\hline Christianity & $66(21.0)$ & & 43 (19.1) & \\
\hline Islam & $58(22.8)$ & & $73(32.6)$ & \\
\hline $\begin{array}{l}\text { School } \\
\text { composition }\end{array}$ & & 0.277 & & 0.005 \\
\hline Girls only & $17(20.5)$ & & $6(9.7)$ & \\
\hline Boys only & $20(16.8)$ & & 35 (31.8) & \\
\hline Mixed & $90(23.6)$ & & $79(27.2)$ & \\
\hline
\end{tabular}

HPV: human papillomavirus. *All percentages were calculated based on the total number of eligible respondents per category (i.e. total responses per category/total number of eligible respondents). \#Only the data on sociodemographic variables that yielded statistically significant comparisons with HPV knowledge and/or HPV vaccine knowledge, are presented.

\section{Factors predicting awareness and knowledge of HPV}

We found that class, school composition, age, state (location of school), and tribe, were factors that predicted the likelihood of HPV awareness among our respondents (Table 4). For example, those respondents that were attending girlsonly (OR=2.86; 95\% CI: 1.93-4.24) had the highest odds when compared with those attending other school types. Similarly, those in SS3 (OR=1.36; 95\% CI: 1.00-1.84) had the highest odds when compared with those in other classes, while those schooling in Bauchi state $(\mathrm{OR}=2.56$; 95\% CI: 1.47-4.51) had the highest odds when compared with those schooling in other states.

However, only gender and state were the factors that predicted a deeper understanding (knowledge) of HPV among our respondents (Table 5). Pertinently, the males were found to have higher odds $(\mathrm{OR}=1.76$; $95 \% \mathrm{CI}$ : $1.14-$ 2.71) than females on the likelihood of having an average or above average knowledge score on HPV, while those schooling in Oyo state (OR=2.78; 95\% CI: $1.05-7.34$ ) had the highest odds of having an average or above average knowledge score on HPV when compared with those schooling in the other surveyed states.

\section{Factors predicting awareness and knowledge of HPV vaccine}

We found that class, school composition, age, state (location of school), and tribe were factors that predicted the likelihood of the respondents' awareness on HPV vaccine (Table 4). For instance, those respondents that were attending a girls-only school $(\mathrm{OR}=2.80$; 95\% CI: $1.84-$ 4.27 ) had the highest odds of being aware of the vaccine

Table 4. Predictors of respondents' awareness of HPV and HPV vaccine

\begin{tabular}{|c|c|c|c|c|}
\hline \multirow[t]{2}{*}{ Variable } & \multicolumn{2}{|c|}{ Aware of HPV } & \multicolumn{2}{|c|}{ Aware of HPV vaccine } \\
\hline & OR & $95 \% \mathrm{CI}$ & OR & $95 \% \mathrm{CI}$ \\
\hline \multicolumn{5}{|l|}{ Class } \\
\hline SS3 & 1.36 & $1.00-1.84$ & 1.208 & $0.88-1.66$ \\
\hline SS2 & 1.28 & $0.98-1.72$ & 1.308 & $0.96-1.78$ \\
\hline SS1 (Ref.) & 1 & & 1 & \\
\hline \multicolumn{5}{|l|}{ School composition } \\
\hline Girls only & 2.86 & $1.93-4.24$ & 2.80 & $1.84-4.27$ \\
\hline Boys only & 1.66 & $1.17-2.37$ & 2.01 & $1.38-2.92$ \\
\hline Mixed (Ref.) & 1 & & 1 & \\
\hline \multicolumn{5}{|l|}{ Age (years) } \\
\hline Early adolescence (10-14) & 0.65 & $0.37-1.14$ & 0.77 & $0.42-1.40$ \\
\hline Late adolescence (15-19) & 0.63 & $0.40-0.98$ & 0.71 & $0.44-1.14$ \\
\hline Youth ( $\geq 20$ ) (Ref.) & 1 & & 1 & \\
\hline \multicolumn{5}{|l|}{ State } \\
\hline Osun & 0.68 & $0.41-1.11$ & 0.95 & $0.55-1.63$ \\
\hline
\end{tabular}


Table 4. Continued

\begin{tabular}{|c|c|c|c|c|}
\hline \multirow[t]{2}{*}{ Variable } & \multicolumn{2}{|c|}{ Aware of HPV } & \multicolumn{2}{|c|}{ Aware of HPV vaccine } \\
\hline & OR & $95 \%$ CI & OR & $95 \%$ CI \\
\hline Оуо & 0.85 & $0.50-1.43$ & 1.28 & $0.72-2.28$ \\
\hline Bauchi & 2.58 & $1.47-4.51$ & 2.87 & $1.55-5.33$ \\
\hline Sokoto & 0.55 & $0.32-0.93$ & 0.62 & $0.35-1.10$ \\
\hline Edo & 0.71 & $0.47-1.08$ & 0.73 & $0.46-1.16$ \\
\hline Benue (Ref.) & 1 & & 1 & \\
\hline \multicolumn{5}{|l|}{ Tribe } \\
\hline Yoruba & 1.44 & $0.96-2.16$ & 1.15 & $0.73-1.81$ \\
\hline Hausa & 1.34 & $0.87-2.07$ & 2.41 & $1.51-3.85$ \\
\hline Igbo & 1.10 & $0.74-1.62$ & 1.07 & $0.70-1.65$ \\
\hline Other (Ref.) & 1 & & 1 & \\
\hline
\end{tabular}

OR: odds ratio. CI: confidence interval. HPV: human papillomavirus.

Table 5. Predictors of having an average and above knowledge of HPV among respondents

\begin{tabular}{l|c|c|}
\hline \multirow{2}{*}{ Variable } & \multicolumn{2}{c}{ Average and above knowledge } \\
\cline { 2 - 3 } Gender & OR & $95 \% \mathrm{CI}$ \\
\hline Male & 1.76 & $1.14-2.71$ \\
Female (Ref.) & 1 & \\
\hline State & & \\
\hline Osun & 2.71 & $1.02-7.24$ \\
Oyo & 2.78 & $1.05-7.34$ \\
Bauchi & 0.81 & $0.34-1.94$ \\
Sokoto & 0.51 & $0.17-1.51$ \\
Edo & 1.00 & $0.45-2.25$ \\
Benue (Ref.) & 1 & \\
\hline
\end{tabular}

OR: odds ratio. $\mathrm{CI}$ : confidence interval.

when compared with those from other school types, while schooling in Bauchi state (OR=2.87; 95\% CI: 1.55-5.33) had the highest odds of respondents' awareness on HPV vaccine when compared with those schooling in other states.

However, only family background, gender and state were the factors that predicted a deeper understanding (knowledge) of HPV vaccine among our respondents (Table 6). Furthermore, our findings showed that the males had higher odds (OR=2.89; 95\% CI: 1.53-5.45) than females when it comes to having above average knowledge score on HPV vaccine knowledge assessment. Also, those respondents who were schooling in Sokoto state $(\mathrm{OR}=4.64 ; 95 \% \mathrm{CI}$ : $1.32-16.28)$ or coming from a polygamous family $(\mathrm{OR}=1.83$; 95\% CI: 1.08-3.10) had higher odds than those in their counterpart groups (Table 6).
Table 6. Predictors of having an above average knowledge of HPV vaccine among respondents

\begin{tabular}{l|l|c|}
\hline & \multicolumn{2}{c|}{ Above average knowledge } \\
\cline { 2 - 3 } & OR & $95 \%$ CI \\
\hline Family background & & \\
Polygamous/Other & 1.83 & $1.08-3.10$ \\
Single parent & 1.19 & $0.57-2.46$ \\
Monogamous (Ref.) & 1 & \\
\hline
\end{tabular}

\begin{tabular}{llc}
$\begin{array}{l}\text { Gender (without } \\
\text { transgender) }\end{array}$ & \\
\hline Male & 2.89 & $1.53-5.45$ \\
Female (Ref.) & 1 & \\
State & & \\
Osun & 0.92 & $0.24-3.60$ \\
Oyo & 0.89 & $0.21-3.75$ \\
Bauchi & 3.26 & $0.99-10.74$ \\
Sokoto & 4.64 & $1.32-16.28$ \\
Edo & 2.43 & $0.79-7.44$ \\
Benue (Ref.) & 1 & \\
\hline
\end{tabular}

OR: odds ratio. CI: confidence interval.

\section{DISCUSSION}

This study surveyed 2530 secondary school students in Nigeria on their awareness and understanding of HPV and HPV vaccine and the findings are quite noteworthy.

Looking at the sociodemographic characteristics of the respondents, we observed that the study sample was very representative and diversified. The gender distribution of the surveyed respondents was fairly even. Also, all the three major Nigerian tribes (Yoruba, Hausa, and Igbo) were well represented in the study. However, the distribution of the 
respondents based on their religious faiths was skewed; only a very negligible number of our respondents who were practicing traditional religions participated in the study; this skewedness is expected because traditional religion is practiced only by a minority of Nigeria's population ${ }^{50}$. Also, all forms of schools (such as boys-only, girls-only, mixed schools, private schools, public schools etc.) were included in the survey.

A large majority of the respondents were unaware of HPV and HPV vaccine. This finding is consistent with other published studies exploring awareness of HPV and HPV vaccine among Nigerian adolescents and young adults ${ }^{51-53}$. Furthermore, the generally low awareness rate of HPV and HPV vaccine in Nigeria is similar to that in high-income countries and other middle-income countries; this shows that low awareness rate on HPV and HPV vaccine among young persons is a global phenomenon, and not just limited to Nigeria ${ }^{54-57}$.

This study also shows that media and internet were the most commonly utilized sources of information on HPV and HPV vaccines among the respondents. This finding supports another study that reported that media and internet are top sources of information on HPV and HPV vaccine among high school students ${ }^{58}$. Also, the above confirm that media and internet are very powerful tools that can be judiciously used for disseminating information among Nigerian secondary school students, especially on issues pertaining to health. However, there are some other sources of information on HPV and HPV vaccine that were also utilized by the surveyed respondents. These sources include friends, parents, and health workers. However, this finding strengthens some Nigerian studies that reported that friends, health workers and parents can be a source of information on HPV and HPV vaccine $^{41,59-62}$.

It is also noteworthy that many of those respondents who claimed awareness of HPV and HPV vaccines actually lacked adequate knowledge of HPV and HPV vaccines. This may suggest that their sources of information on HPV and HPV vaccine were probably inadequate or misleading; however, this suggestion is supported by previous studies, which reported that the quality of some health-related information shared among people, especially via the internet and social media, is unreliable ${ }^{63}$. This implies that all health-related information obtained from the internet and social media must first be scrutinized with extreme caution before its acceptance.

Also in this study, we observed that those respondents that belonged to a single sex (boys-only or girls-only) school, SS3 class, and a school located in Bauchi state, were more likely to be aware of HPV and HPV vaccine than their counterpart groups. These observations are very interesting, although not too surprising because: 1) most school-based health education programs in Nigeria are on reproductive health and commonly conducted at single-sex schools60; this may be a strong reason why students from single sex schools are more likely to be aware about HPV and HPV vaccines than those in mixed-sex schools; 2) The SS3 class is the highest level in the Nigerian senior secondary schools, nationwide; hence they are expected to be more knowledgeable than those in the junior classes due to their higher level of maturity and exposure to more information than the junior classes. However, based on the existing data and our knowledge of Bauchi state, we find it very difficult to explain how schooling in the state increases a student's likelihood of awareness about HPV and HPV vaccine. Hence, this calls for future studies that will deeply explore this particular knowledge gap.

Interestingly, some factors were found to reduce the likelihood of the respondents' awareness or understanding about HPV and HPV vaccine. Such factors include schooling in Sokoto state and having a polygamous family background. The reasons why those respondents in these categories had the likelihood of lacking knowledge or awareness about HPV and HPV vaccine cannot be ascertained based on the findings of the present study; hence, it will be worthwhile to conduct a study that will explore these area in the future.

However, it can be inferred from this study that many young in-school Nigerians are at high risk of developing $\mathrm{HPV}$-associated diseases including HPV-induced cancers; this inference was made based on the observed low level of awareness of HPV and HPV vaccine among them. Unfortunately, among the infectious disease types ever known to man, HPV-induced cancers are among the notorious types ${ }^{13,14}$. Importantly, adequate knowledge about a disease goes a long way in the prevention of such disease ${ }^{60}$; if the youth in Nigeria are not made knowledgeable about HPV and preventive measures (such as HPV vaccination and the practice of safe sexual intercourse), then they stand a high risk of contracting HPV infections in the future.

\section{Strengths and limitations}

This study has limitations. This study adopted the use of convenience sampling technique (a non-probability sampling technique) in the selection of the schools that participated in the study; this gave all the schools in the participating states an unequal chance of participating in the study. Also, not all the states in Nigeria were included in the study due to limited financial and human resources.

Notwithstanding the limitations, this study is believed to be the largest survey assessing the knowledge of HPV and HPV vaccines among senior secondary school students in Nigeria. Furthermore, this study was conducted at a period when the Nigerian government is yet to introduce HPV vaccination into the national immunization programs in Nigeria $^{22,23}$. Hence, the findings obtained in this study will provide additional relevant information to the government and all other relevant stakeholders towards the formulation and implementation of HPV sensitization and immunization policies and programs in Nigeria. 


\section{Recommendations}

Based on our findings and our discussion so far, we make the following recommendations. First, a nationally representative study that will determine the prevalence of risks of contracting HPV infection (such as unprotected sexual intercourse, sexual violence etc.) among in-school youth in Nigeria needs to be conducted. Second, a nationwide school-based campaign/sensitization on HPV prevention (with focus on HPV-induced cancers) among young people in Nigeria needs to be conducted. Third, the Federal Government of Nigeria needs to quickly introduce HPV vaccine into the routine immunization program of Nigeria to curb the spread of HPV infection in Nigeria.

\section{CONCLUSIONS}

This study suggests that most of the senior secondary school students in Nigeria lacked adequate knowledge of HPV and HPV vaccines. Pertinently, their lack of knowledge of HPV and HPV vaccine places them at very high risk of contracting HPV infections.

\section{REFERENCES}

1. Mcmurray HR, Nguyen D, Westbrook TF, Mcance DJ. Biology of human papillomaviruses. Int J Exp Pathol. 2001;82(1):1533. doi:10.1046/j.1365-2613.2001.00177.x

2. Lajer CB, von Buchwald C. The role of human papillomavirus in head and neck cancer. APMIS. 2010;118(6-7):510-519. doi:10.1111/j.1600-0463.2010.02624.x

3. Braaten KP, Laufer MR. Human papillomavirus (HPV), HPVrelated disease, and the HPV vaccine. Rev Obstet Gynecol. 2008;1(1):2-10. PMID:18701931.

4. Muñoz N, Bosch FX, de Sanjosé S, et al. Epidemiologic classification of human papillomavirus types associated with cervical cancer. N Engl J Med. 2003;348(6):518-527. doi:10.1056/NEJMoa021641

5. Münger K, Howley PM. Human papillomavirus immortalization and transformation functions. Virus Res. 2002;89(2):213-228. doi:10.1016/s0168-1702(02)00190-9

6. Husain N, Neyaz A. Human papillomavirus associated head and neck squamous cell carcinoma: Controversies and new concepts. J Oral Biol Craniofac Res. 2017;7(3):198-205. doi:10.1016/j.jobcr.2017.08.003

7. Westra WH. The morphologic profile of HPV-related head and neck squamous carcinoma: implications for diagnosis, prognosis, and clinical management. Head Neck Pathol. 2012;6(Suppl 1):48-54. doi:10.1007/s12105-012-0371-6

8. Bishop JA, Westra WH. Human papillomavirus-related small cell carcinoma of the oropharynx. Am J Surg Pathol. 2011;35(11):1679-1684. doi:10.1097/PAS.0b013e3182299cde

9. Bosch FX, Lorincz A, Muñoz N, Meijer CJLM, Shah KV. The causal relation between human papillomavirus and cervical cancer. J Clin Pathol. 2002;55:244-265. doi:10.1136/jcp.55.4.244

10. Garland SM, Steben M, Sings HL, et al. Natural history of genital warts: analysis of the placebo arm of 2 randomized phase III trials of a quadrivalent human papillomavirus (types 6, 11, 16, and 18) vaccine. J Infect Dis.
2009;199(6):805-814. doi:10.1086/597071

11. Somers GR, Tabrizi SN, Borg AJ, Garland SM, Chow CW. Juvenile laryngeal papillomatosis in a pediatric population: a clinicopathologic study. Pediatr Pathol Lab Med. 1997;17(1):53-64. PMID:9050060.

12. Lee LY, Garland SM. Human papillomavirus vaccination: the population impact. F1000Res. 2017;6:866. doi:10.12688/f1000research.10691.1

13. World Health Organization. Immunization, Vaccines and Biologicals: Research and development. Geneva, Switzerland: World Health Organization; 2017. http://www.who.int/ vaccine_research/diseases/hpv/en/. Accessed July 16, 2020.

14. Kreimer AR, Alberg AJ, Daniel R, et al. Oral human papillomavirus infection in adults is associated with sexual behavior and HIV serostatus. J Infect Dis. 2004;189(4):686698. doi:10.1086/381504

15. Kjaer SK, Chackerian B, van den Brule AJ, et al. High-risk human papillomavirus is sexually transmitted: evidence from a follow-up study of virgins starting sexual activity (intercourse). Cancer Epidemiol Biomarkers Prev. 2001;10(2):101-106. PMID:11219765.

16. Winer RL, Lee SK, Hughes JP, Adam DE, Kiviat NB, Koutsky LA. Genital human papillomavirus infection: incidence and risk factors in a cohort of female university students. Am J Epidemiol. 2003;157(3):218-226. doi:10.1093/aje/kwf180

17. Kashima H, Leventhal B, Mounts P, et al. Scoring system to assess severity and course in recurrent respiratory papillomatosis. In: Howley PM, Broker TR, eds. Papillomaviruses: Molecular and clinical aspects. New York, NY: Alan R. Liss Inc.; 1985:125-135.

18. Fredericks BD, Balkin A, Daniel HW, Schonrock J, Ward B, Frazer IH. Transmission of human papillomaviruses from mother to child. Aust N Z J Obstet Gynaecol. 1993;33(1):3032. doi:10.1111/j.1479-828x.1993.tb02047.x

19. Austin DF, Reynolds P. Laryngeal cancer. In: Schottenfeld D, Fraumeni JF, eds. Cancer Epidemiology and Prevention. 2nd Ed. Oxford, UK: Oxford University Press; 1996:619-636.

20. Rodríguez AC, Schiffman M, Herrero R, et al. Rapid clearance of human papillomavirus and implications for clinical focus on persistent infections. J Natl Cancer Inst. 2008;100(7):513517. doi:10.1093/jnci/djn044

21. Patel C, Brotherton JML, Pillsbury A, Jayasinghe S, Donovan B, Macartney K, Marshall H. The impact of 10 years of human papillomavirus (HPV) vaccination in Australia: what additional disease burden will a nonavalent vaccine prevent?. Euro Surveill. 2018;23(41):1700737. doi:10.2807/1560-7917.ES.2018.23.41.1700737

22. Lekoane KMB, Kuupiel D, Mashamba-Thompson TP, Ginindza TG. Evidence on the prevalence, incidence, mortality and trends of human papilloma virus-associated cancers in subSaharan Africa: systematic scoping review. BMC Cancer. 2019;19(1):563. doi:10.1186/s12885-019-5781-3

23. Vuyst HD, Alemany L, Lacey $C$, et al. The Burden of Human Papillomavirus Infections and Related Diseases in Sub-Saharan Africa. Vaccine. 2013;31(0_5):F32-F46. 
doi:10.1016/j.vaccine.2012.07.092

24. Ritchwood TD, Ford H, DeCoster J, Sutton M, Lochman JE. Risky Sexual Behavior and Substance Use among Adolescents: A Meta-analysis. Child Youth Serv Rev. 2015;52:74-88. doi:10.1016/j.childyouth.2015.03.005

25. Moscicki AB. Impact of HPV infection in adolescent populations. J Adolesc Health. 2005;37(6 Suppl):S3-S9. doi:10.1016/j.jadohealth.2005.09.011

26. Panatto D, Amicizia D, Trucchi C, et al. Sexual behaviour and risk factors for the acquisition of human papillomavirus infections in young people in Italy: suggestions for future vaccination policies. BMC Public Health. 2012;12:623. doi:10.1186/1471-2458-12-623

27. Odeigah L, Rasaki SO, Ajibola AF, Hafsat AA, Sule AG, Musah Y. High risk sexual behavior among adolescent senior secondary school students in Nigeria. Afr Health Sci. 2019;19(1):1467-1477. doi:10.4314/ahs.v19i1.20

28. Chimah UC, Nnebue CC, Ilika AL, Lawoyin TO. Sexual behavioral pattern, consequences and adopted solutions among senior secondary schools students in a military barracks in Nigeria. Int J Adolesc Med Health. 2016;28(2):203-210. doi:10.1515/ijamh-2015-0012

29. Ajuwon AJ, Olaleye A, Faromoju B, Ladipo O. Sexual behavior and experience of sexual coercion among secondary school students in three states in North Eastern Nigeria. BMC Public Health. 2006;6:310. doi:10.1186/1471-2458-6-310

30. Slap GB, Lot L, Huang B, Daniyam CA, Zink TM, Succop PA. Sexual behaviour of adolescents in Nigeria: cross sectional survey of secondary school students. BMJ. 2003;326(7379):15. doi:10.1136/bmj.326.7379.15

31. Odimegwu C, Somefun OD. Ethnicity, gender and risky sexual behaviour among Nigeria youth: an alternative explanation. Reprod Health. 2017;14(1):16. doi:10.1186/s12978-017-0284-7

32. Folayan MO, Adebajo S, Adeyemi A, Ogungbemi KM. Differences in Sexual Practices, Sexual Behavior and HIV Risk Profile between Adolescents and Young Persons in Rural and Urban Nigeria. PLoS One. 2015;10(7):e0129106. doi:10.1371/journal.pone.0129106

33. Mohammed FA, Kanmodi KK, Fagbule OF, Adesina MA, Njideka NJ, Sadiq HA. Shisha smokers' desire to quit shisha smoking habit: Findings from a Nigerian pilot survey. Global Psychiatry. 2019;2(1):37-42. doi:10.2478/gp-2019-0004

34. Kanmodi KK, Fagbule OF, Aladelusi TO. Prevalence of shisha (waterpipe) smoking and awareness of head and neck cancer among Nigerian secondary school students: A preliminary survey. Int Public Health J. 2018;10(2):209-214. https:// www.researchgate.net/publication/323258643_Prevalence_ of_shisha_waterpipe_smoking_and_awareness_of_head_and_ neck_cancer_among_Nigerian_secondary_school_students_A_ preliminary_survey. Accessed July 16, 2020.

35. Adesina MA, Kanmodi KK, Fagbule OF, Ogunmuko T. Unfavorable family background is associated with smoking at youthful age. Int J Child Health Hum Dev. 2019;12(2):139144.

36. Mohammed FA, Njideka NJ, Aliyu BM, Kanmodi KK, Fagbule
OF, Ogbeide ME. Attitudes of a snowballed sample of Nigerian hookah (shisha) smokers toward tobacco ban: A short report. Int J Disabil Hum Dev. 2019;18(2):in press.

37. Badru AI, Kanmodi KK, Ogundipe PA, Owadokun AM, Adesina MA. Opinions of Nigerian religious leaders and seminarians on what causes cancer: A short report. J Altern Med Res. 2019;11(2):165-167.

38. Kanmodi KK, Mohammed FA, Nwafor NJ, Fagbule OF, Adesina MA, Aliyu BM, Ogundipe PA. Poor knowledge of the harmful effects of shisha among shisha smokers: Findings from a preliminary survey in Northwest Nigeria. Med Univ. 2019;2(2):49-56. doi:10.2478/medu-2019-0009

39. Kanmodi KK, Fagbule FO. Does head and neck cancer (HNC) education have impact on adolescents' knowledge and attitude towards HNC and HNC peer education? An example from Nigeria. Int J Child Adolesc Health. 2018;11(3):343347.

40. Fagbule OF, Kanmodi KK, Aladelusi TO. Secondhand tobacco smoke exposure and attitudes towards tobacco ban: A pilot survey of secondary school students in Ibokun Town, Nigeria. Int J Child Adolesc Health. 2018;11(3):349-353. https://www.researchgate.net/publication/322696428_ Secondhand_tobacco_smoke_exposure_and_attitudes_ towards_tobacco_ban_A_pilot_survey_of_secondary_school_ students_in_Ibokun_Town_Nigeria. Accessed July 16, 2020.

41. Kanmodi KK, Ogbeide ME, Fagbule OF, Omoleke SA, Isola TO, Ogundipe PA. Do college freshmen know about head and neck cancer and its risk factors? Experience from Gwadabawa, Nigeria. Int J Med Res Health Sci. 2019;8(9):111-116. https://www.ijmrhs.com/medicalresearch/do-college-freshmen-know-about-head-and-neckcancer-and-its-risk-factors-experience-from-gwadabawanigeria.pdf. Accessed July 16, 2020.

42. Kanmodi KK, Mohammed FA,Omoleke SA, et al. Head and neck cancer risk factors among a pilot sample of Nigerian shisha smokers: Focus on oral sex, tobacco, alcohol, and knowledge of head and neck cancer. J Dent Orofac Res. 2019;15(2):49-57. http://www.jdorjournal.com/pdf/ archives/August2019/8.pdf. Accessed July 16, 2020.

43. Maness SB, Reitzel LR, Watkins KL, McNeill LH. HPV awareness, knowledge and vaccination attitudes among church-going African-American Women. Am J Health Behav. 2016;40(6):771-778. doi:10.5993/AJHB.40.6.9

44. Yu Y, Xu M, Sun J, et al. Human papillomavirus infection and vaccination: awareness and knowledge of HPV and acceptability of HPV vaccine among mothers of teenage daughters in Weihai, Shandong, China. PLoS ONE. 2016;11(1): e0146741. doi:10.1371/journal.pone.0146741

45. Marlow LAV, Zimet GD, McCaffery KJ, Ostini R, Waller J. Knowledge of human papillomavirus (HPV) and HPV vaccination: An international comparison. Vaccine. 2013;31(5):763-769. doi:10.1016/j.vaccine.2012.11.083

46. Marek E, Dergez T, Rebek-Nagy G, et al. Adolescents' awareness of HPV infections and attitudes towards HPV vaccination 3 years following the introduction of the HPV 
vaccine in Hungary. Vaccine. 2011;29(47):8591-8598. doi:10.1016/j.vaccine.2011.09.018

47. Bowyer HL, Marlow LAV, Hibbitts S, Pollock KG, Waller J. Knowledge and awareness of HPV and the HPV vaccine among young women in the first routinely vaccinated cohort in England. Vaccine. 2013;31(7):1051-1056. doi:10.1016/j.vaccine.2012.12.038

48. Lambert EC. College students' knowledge of human papillomavirus and effectiveness of a brief educational intervention. J Am Board Fam Pract. 2001;14(3):178-183. PMID:11355049.

49. Blumenthal J, Frey MK, Worley Jr MJ, Tchabo NE, Soren K, Slomovitz BM. Adolescent understanding and acceptance of the HPV vaccination in an underserved population in New York City. J Oncol. 2012:1-8. doi:10.1155/2012/904034

50. Sampson IT. Religious violence in Nigeria: causal diagnoses and strategic recommendations to the state and religious communities. Afr J Conflict Resol. 2012;12(1):103-134. https:// www.ajol.info/index.php/ajcr/article/view/78703/69042. Accessed July 16, 2020.

51. Diorgu FC, Diorgu KN. Awareness of HPV infection and vaccination among teens in urban high school. ARCH Women Health Care. 2019;2(2):1-3. https://researchopenworld. com/wp-content/uploads/2019/04/AWHC-2019-111-FaithChinaemerem-USA.pdf. Accessed July 16, 2020.

52. Sadoh AE, Okonkwo C, Nwaneri DU, Ogboghodo BC, Eregie C, Oviawe O, Famuyiwa O. Effect of peer education on knowledge of human papilloma virus and cervical cancer among female adolescent students in Benin City, Nigeria. Ann Global Health. 2018;84(1):121-128. doi:10.29024/aogh.24

53. Ojimah C, Maduka O. Awareness and uptake of human papillomavirus vaccines among female undergraduate students: Implications for cervical cancer prevention in South-South, Nigeria. Port Harcourt Med J. 2017;11(3):134140. doi:10.4103/phmj.phmj_14_17

54. Ramavath KK, Olyai R. Knowledge and awareness of HPV infection and vaccination among urban adolescents in india: a cross-sectional study. J Obstet Gynaecol India. 2013;63(6):399-404. doi:10.1007/s13224-013-0413-3

55. Liu CR, Liang H, Zhang X, et al. Effect of an educational intervention on HPV knowledge and attitudes towards HPV and its vaccines among junior middle school students in Chengdu, China. BMC Public Health. 2019;19(1):488. doi:10.1186/s12889-019-6823-0

\section{ACKNOWLEDGEMENTS}

The authors are grateful to Cephas Health Research Initiative Inc for funding the study. Also, all participating schools and students are duly appreciated.

\section{CONFLICTS OF INTEREST}

The authors have completed and submitted the ICMJE Form for Disclosure of Potential Conflicts of Interest and none was reported.
56. Patel H, Pcolkina K, Stradzina K, et al. Awareness of HPV infection and attitudes toward HPV vaccination among Latvian adolescents. Int J Gynaecol Obstet. 2017;137(2):138144. doi:10.1002/ijgo.12117

57. Patel H, Jeve YB, Sherman SM, Moss EL. Knowledge of human papillomavirus and the human papillomavirus vaccine in European adolescents: a systematic review. Sex Transm Infect. 2016;92(6):474-479. doi:10.1136/sextrans-2015-052341

58. Rosen BL, Shew ML, Zimet GD, Ding L, Mullins TLK, Kahn JA. Human Papillomavirus Vaccine Sources of Information and Adolescents' Knowledge and Perceptions. Glob Pediatr Health. 2017;4:2333794X17743405. doi:10.1177/2333794X17743405

59. Kanmodi KK, Chidiebere O, Nwafor NJ, Amoo BA. Knowledge of HPV, HPV-induced cancers, and HPV vaccine among university students in medical laboratory science disciplines: Nigerian study. J Obstet Gynecol Investig. 2020;3:e10-e16. doi:10.5114/jogi.2020.94420

60. Kanmodi KK, Osunro KS, Nwafor NJ, Kanmodi PA. Impact of head and neck cancer (HNC) education on HNC knowledge and attitudes toward HNC peer and non-peer education: A school-based pilot study. Yen Med J. 2020;2(2):4755. https://yenagoamedicaljournal.net/wp-content/ uploads/2020/06/Impact-of-head-and-neck-cancer-HNCeducation-on-HNC-knowledge-and-attitudes-toward-HNCpeer-and-non-peer-education-A-school-based-pilot-study. pdf. Accessed July 16, 2020.

61. Ohareri B, Adefolaju AO, Onyeneho CA. Knowledge, attitudes and perceptions of Nigerian parents towards human papilloma virus (HPV) vaccines. Eur J Midwifery. 2020;4(January). doi:10.18332/ejm/114886

62. Ojiyi CE, Dike EI, Okuedo C, Nzewuihe AC, Uzoma MJK. Human papilloma virus vaccine: Awareness and acceptability amongst female medical students and health workers in a university teaching hospital in Eastern Nigeria. Nig J Surg Sci. 2013;23(1):14-17. doi:10.4103/1116-5898.127102

63. Kanmodi KK, Adegbile OE, Ogidan IO, Kanmodi PA. What are we learning on social media about shisha? A case study of top 50 short English YouTube shisha videos. Yenagoa Medical Journal. 2020;2(4):38-47. https://yenagoamedicaljournal. net/wp-content/uploads/2020/09/What-are-we-learningon-social-media-about-shisha-A-case-study-of-top-50-shortEnglish-youtube-shisha-videos.pdf. Accessed July 16, 2020.

AUTHORS' CONTRIBUTIONS

Study conceptualization: KKK, OFF; protocol design: KKK, OFF; data collection: all authors except SAO and PAK; data analysis: OFF, KKK; manuscript drafting: KKK, OFF; review of drafts: all authors; final draft review: all authors. Note: KKK and OFF contributed equally to the study.

PROVENANCE AND PEER REVIEW

Not commissioned; externally peer reviewed.

FUNDING

There was no source of funding for this research. 